\title{
Antibodies against cyclic citrullinated peptide don't decrease after 6 months of infliximab treatment in refractory rheumatoid arthritis
}

\author{
Bogdan Kolarz • Maria Majdan • Magdalena Dryglewska \\ Dorota Darmochwal-Kolarz
}

Received: 13 January 2010/Accepted: 27 April 2010/Published online: 15 May 2010

(C) The Author(s) 2010. This article is published with open access at Springerlink.com

\begin{abstract}
Anti-citrullinated peptide antibodies (ACPA) and the rheumatoid factor (RF) are well-established serological markers for rheumatoid arthritis (RA). ACPA are very useful in the diagnosis of RA, especially at the early stages of the disease when ACPA have a greater diagnostic value than RF. The aim of the study was to assess the influence of infliximab treatment on RF IgM and ACPA serum levels and RA activity during 6 months of treatment. Thirty-two patients with refractory RA were treated with infliximab during a 6-month period. At baseline, 3 and 6 months of treatment the patients were examined for the number swollen and tender joints out of 28 (SJC, TJC) and the visual analogue scale of arthritis activity according to the patient (VAS). Serum samples were tested for erythrocyte sedimentation rate (ESR), C-reactive protein level (CRP), ACPA and RF IgM. The disease activity score (DAS-28) parameter was also calculated at the same time. During the course of our study, we observed statistically significant improvement in ESR, CRP, TJC, SJC, VAS DAS-28, and RF IgM after 3 and 6 months of infliximab treatment when compared to the baseline, whereas the ACPA level remained unchanged after 3 and 6 months of treatment $(P=0.96$ and $P=0.85)$. The changes in the ACPA level are not a factor for evaluation of successful infliximab treatment but the changes
\end{abstract}

\section{B. Kolarz $(\bowtie)$}

Department of Family Medicine, Medical University of Lublin, ul. Staszica 11, 20-081 Lublin, Poland

e-mail: kolbo@wp.pl

M. Majdan · M. Dryglewska

Department of Rheumatology and Connective Tissue Diseases,

Medical University of Lublin, ul. Jaczewskiego 8,

20-850 Lublin, Poland

D. Darmochwal-Kolarz

Department of Obstetrics and Perinatology, Medical University of Lublin, ul. Jaczewskiego 8, 20-950 Lublin, Poland in RF IgM are. According to different behavior of these antibodies during infliximab treatment, we suggest that the roles of ACPA and RF in the pathogenesis of RA are different.

Keywords Anti-citrullinated peptide antibodies . Rheumatoid arthritis · Infliximab ·

Tumor necrosis factor antagonists

\section{Introduction}

Rheumatoid arthritis (RA) is a chronic systemic inflammatory disease that afflicts the synovium of diarthrodial joints and is characterized by synovial inflammation leading to cartilage destruction, bone erosion and eventually to disability of the patient.

The etiology of RA still remains elusive although the disease is known to be of autoimmune origin. Supportive findings for this theory are the presence of $\operatorname{IgG}$ autoantibodies, such as the rheumatoid factor (RF), and anticitrullinated peptide antibodies (ACPA). The process called citrullination relies upon posttranslational deimination of arginine and its conversion to a new, non-standard aminoacid-citrulline. Arginine is a positively charged aminoacid but citrulline is neutral.

The production of ACPA is strongly associated with MHC class II molecules that contain a motif known as the shared epitope, such as HLA-DRB $1 * 0401$, and subsequent CD4 cells activation [1].

ACPA are up to $98.5 \%$ specific and $70 \%$ sensitive to rheumatoid arthritis (RA) [2-4], and may be detected very early in the disease, even prior to the onset of clinical symptoms $[5,6]$. There are also data proving that the presence of ACPA has a prognostic value and is highly predictive of more severe radiologic damage compared to ACPA 
negative subjects [7]. Less than $2 \%$ of healthy population have these antibodies. Moreover, few patients with other rheumatic diseases are positive, with some exceptions of other conditions with clinical similarities to RA [8].

The new biologic methods of treatment of RA using anti-TNF agents (i.e., infliximab) are effective in patients with refractory RA. The majority of infliximab-treated patients present improvement in clinical symptoms and signs of RA and laboratory markers of inflammation, such as C-reactive protein (CRP) [9-11]. On the other hand, up to $25 \%$ of treated patients have a poor response to this kind of treatment [12]. There are no reliable factors to predict the response to treatment. The rheumatoid factor (RF) usually decreases during successful treatment [13-15]. Data concerning influence of infliximab treatment on the serum level of aCCP antibodies are contrary [14, 16]. A significant number of patients with RA (up to $40 \%$ ) experience early development of joint destruction [17]. Quick and successful treatment of this group of patients is very important, so is early separating of unresponsive patients.

The aim of the study was to assess the influence of infliximab treatment on RF IgM and ACPA serum levels and RA activity during 6 months of treatment.

\section{Materials and methods}

Thirty-two patients with refractory RA were enrolled in the study (28 females and seven males, mean 45.4 years, range from 19 to 60 ). All of them were RF positive and 25 out of $32(78 \%)$ were aCCP positive. The patients were treated at the Department of Rheumatology and Connective Tissue Diseases, Medical University of Lublin.

All patients had a history of failed treatment with at least one disease modifying antirheumatic drug (DMARD). Patients were allowed to continue DMARDs, steroids, and non-steroidal anti-inflammatory drugs before and during infliximab treatment. None of the patients had an infectious disease, active or latent tuberculosis, neoplastic disease, heart failure, cytopenia, or a demyelinating disorder.

The patients received $3 \mathrm{mg} / \mathrm{kg}$ infliximab intravenously at weeks $0,2,6$, and every 8 weeks thereafter. Methotrexate was given in a dose of 10-20 mg weekly. In addition to methotrexate, chloroquine (250 mg daily) and steroids (maximum daily dose $10 \mathrm{mg}$ of oral prednisone or equivalent) were also permitted.

Written informed consent was obtained from all patients, and the study was approved by the Bioethics Committee of the University of Lublin.

Blood serum samples were collected from all patients at baseline and after 3 and 6 months of anti-TNF treatment. The sera were stored at $-70^{\circ} \mathrm{C}$ until further analysis.
The patients were examined clinically at baseline and after 3 and 6 months of the study by the same physician during each visit for infliximab infusion. Clinical evaluation included the number of tender (TJC) and swollen (SJC) joints, visual analogue scale of arthritis activity according to the patient (VAS), erythrocyte sedimentation rate (ESR), and C-reactive protein level (CRP). The DAS-28 parameter was used to evaluate clinical activity and the response to treatment.

ACPA were tested using a third-generation commercially available enzyme-linked immunoabsorbent assayELISA, Quanta Life CCP IgG Elisa of Inova, US and RF was determined with ELISA IgM Kit, Euroimmun, Germany. All the serum samples of patients with RA were analyzed in a single session according to the manufacturer's instructions. ACPA levels were measured in arbitrary units per milliliter and were considered to be positive at a cutoff value of $\geq 20 \mathrm{U} / \mathrm{ml}$. The $\mathrm{RF}$ IgM results were presented in relative units per milliliter (RU/ml) with a cutoff value of $20 \mathrm{RU} / \mathrm{ml}$ for a positive result. The CRP level and ESR were measured each time on the day of infliximab infusion.

Statistical analysis was performed using Statistica 7.0 PL software. Differences between groups were analyzed using Mann-Whitney $U$ test. A $P$ value less than 0.05 was considered statistically significant.

\section{Results}

During the course of our study, we observed statistically significant improvement in clinical parameters of RA activity. We noted a significant decrease in ESR, CRP, TJC, SJC, VAS, DAS-28, and RF IgM after 3 and 6 months of infliximab treatment when compared to the baseline. The exact data are presented in Table 1.

The ACPA levels did not exhibit a significant reduction after 3 and 6 months of infliximab treatment (Fig. 1).

The mean baseline level value of ACPA was $716.97 \pm 663.76$, it changed to $728 \pm 678.27$ after 3 months $(P=0.96)$ and to $684.36 \pm 647.8$ after 6 months $(P=0.85)$ of infliximab treatment.

There were no cases of ACPA normalization during this treatment (lowering below $20 \mathrm{U} / \mathrm{ml}$ ).

A significant reduction in RF IgM was observed after 3 and 6 months of treatment, with $P=0.035$ and $P=0.005$, respectively (Fig. 2).

\section{Discussion}

The improvement in clinical and laboratory tests during anti-TNF treatment is now beyond discussion [18-20]. 
Table 1 The results of ACPA, RF IgM, ESR, CRP, DAS-28, TJC, SJC, VAS at baseline, after 3 and 6 months of infliximab treatment of patients with RA

$\# P<0.05$ Baseline to 3 months, $* P<0.05$ Baseline to 6 months

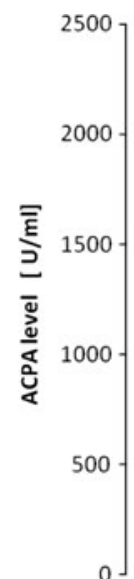

Fig. 1 ACPA levels at baseline and after 3 and 6 months of infliximab treatment of patients with RA

There is evidence that ACPA are very useful in the diagnosis of RA, especially at the early stages of the disease when ACPA have a greater diagnostic value than RF [3].

In our study, the level of ACPA did not significantly change after 3- and 6-month periods of infliximab treatment. The same constellation of results was also found in previous studies $[13,21]$. Other researchers reported a significant reduction in the serum level of ACPA after treatment with adalimumab [22], etanercept and infliximab $[23,24]$. In contrast to these findings, De Rycke et al. observed no significant influence of successful infliximab treatment on the ACPA level after 30 weeks of observation but an evident and significant decrease in RF IgM during such a treatment [16]. Similar data were lately reported by Bruns et al. [25].

The posttranslational conversion of arginine, called citrullination, leads to changes in the modified proteins containing citrulline, leading to changes in the molecular mass and lack of positive charge. The physiological role of this process remains unknown, but it has been suggested that citrullination may play a certain role in disintegration of cells and proteins by apoptosis [26] and regulation of transcription [27].

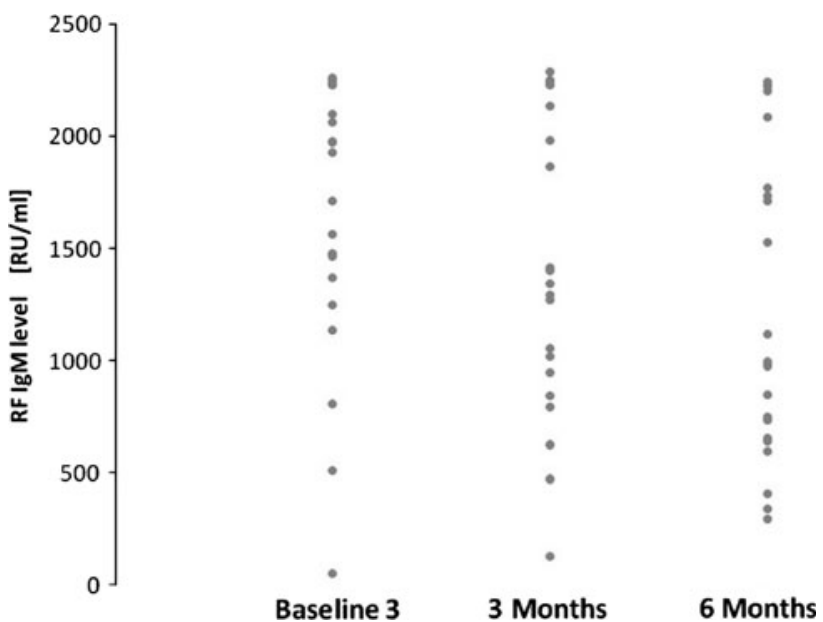

Fig. 2 RF $\operatorname{IgM}$ level at baseline and after 3 and 6 months of infliximab treatment of patients with RA

The presence of ACPA is detectable years before the first symptoms of RA and seems to be very stable during the course of the disease without significant changes from ACPA negative to positive or inversely [28]. According to these authors, ACPA is a stable phenotype during the course of RA. Van Gaalen et al. have shown an association between HLA DRB1 genes and the presence of ACPA. Moreover, it has been observed that only shared epitope-positive patients produce ACPA [29]. Similar data were found by Auger et al. [30]. According to Johanson et al. [31], there is a very strong positive correlation between PTPN22 gene and ACPA production. The above genetic connections of ACPA and their presence at the early stages of RA or even many years before the disease could explain why the ACPA level is so stable and did not change during our observation. The genetic connections of ACPA are known but they need further investigation. As reported by Potter et al. [32], there is a negative correlation between the response to anti-TNF treatment and the absence of RF or ACPA. It contrast, they did not find a correlation with SE or PTPN22 presence in the same group of patients [32].

De Rycke et al. [16] have suggested that RF and ACPA are two different and independent autoantibody systems in RA. These two factors may provide different but complementary information on RA [16]. 
Taking into consideration the differences in the trends of changes concerning ACPA and RF IgM during successful infliximab treatment, we concluded that their roles in the pathogenesis of RA seem to be different. ACPA seems to be more stable and genetically dependent. The impact of short-term infliximab treatment on TNF- $\alpha$ does not influence the expression of genes involved in ACPA production.

\section{Conclusion}

Six months of anti-TNF therapy do not influence ACPA level, contrary to a significant decrease in RF IgM concentration. According to different behavior of these antibodies during infliximab treatment, we suggest that the roles of ACPA and RF IgM in the pathogenesis of RA are different. Further studies are needed to establish the exact role of ACPA and RF IgM in the pathogenesis of RA. Serial ACPA measurements should not be used as an early predictive factor of a good response in infliximab treatment of RA.

Open Access This article is distributed under the terms of the Creative Commons Attribution Noncommercial License which permits any noncommercial use, distribution, and reproduction in any medium, provided the original author(s) and source are credited.

\section{References}

1. Bos WH, Ursum J, de Vries N, Bartelds GM, Wolbink GJ, Nurmohamed MT, van der Horst-Bruinsma IE et al (2008) The role of the shared epitope in arthralgia with anti-cyclic citrullinated peptide antibodies (anti-CCP), and its effect on anti-CCP levels. Ann Rheum Dis 67(9):1347-1350

2. Lee DM, Schur PH (2003) Clinical utility of the anti-CCP assay in patients with rheumatic diseases. Ann Rheum Dis 62(9):870-874

3. De Rycke L, Peene I, Hoffman IE, Kruithof E, Union A, Meheus L, Lebeer K et al (2004) Rheumatoid factor and anticitrullinated protein antibodies in rheumatoid arthritis: diagnostic value, associations with radiological progression rate, and extra-articular manifestations. Ann Rheum Dis 63(12):1587-1593

4. Suzuki K, Sawada T, Murakami A, Matsui T, Tohma S, Nakazono K, Takemura M et al (2003) High diagnostic performance of ELISA detection of antibodies to citrullinated antigens in rheumatoid arthritis. Scand J Rheumatol 32(4):197-204

5. Nielen MMJ, van Schaardenburg D, Reesink HW, van de Stadt RJ, van der Horst-Bruinsma IE, de Koning M, Habibuw MR et al (2004) Specific autoantibodies precede the symptoms of rheumatoid arthritis. Arthritis Rheum 50:380-386

6. Rantap-Dahlqvist S, de Jong BA, Berglin E, Hallmans G, Wadell G, Stenlund H, Sundin U et al (2003) Antibodies against cyclic citrullinated peptide and IgA rheumatoid factor predict the development of rheumatoid arthritis. Arthritis Rheum 48(10):2741-2749

7. Kroot E, De Jong BAW, Van Leeuwen MA, Swinkels H, Van Den Hoogen FHJ, Van't Hof M, Van De Putte LBA et al (2000) The prognostic value of anti-cyclic citrullinated peptide antibody in patients with recent-onset rheumatoid arthritis. Arthritis Rheum 43(8):1831-1835

8. Schellekens GA, Visser H, de Jong BA, van den Hoogen FH, Hazes JM, Breedveld FC, van Venrooij WJ (2000) The diagnostic properties of rheumatoid arthritis antibodies recognizing a cyclic citrullinated peptide. Arthritis Rheum 43(1):155-163

9. Maini R, St Clair EW, Breedveld F, Furst D, Kalden J, Weisman M, Smolen J et al (1999) Infliximab (chimeric antitumour necrosis factor alpha monoclonal antibody) versus placebo in rheumatoid arthritis patients receiving concomitant methotrexate: a randomised phase III trial. ATTRACT Study Group. Lancet 354(9194):1932-1939

10. Charles P, Elliott M, Davis D, Potter A, Kalden J, Antoni C, Breedveld F et al (1999) Regulation of cytokines, cytokine inhibitors, and acute-phase proteins following anti-TNF- $\alpha$ therapy in rheumatoid arthritis. J Immunol 163(3):1521-1528

11. Maini R, Taylor P (2000) Anti-cytokine therapy for rheumatoid arthritis. Annu Rev Med 51(1):207-229

12. Pittoni V, Bombardieri M, Spinelli F, Scrivo R, Alessandri C, Conti F, Spadaro A et al (2002) Anti-tumour necrosis factor (TNF) treatment of rheumatoid arthritis (infliximab) selectively down regulates the production of interleukin (IL) 18 but not of IL12 and IL13. Ann Rheum Dis 61(8):723-725

13. Mikuls TR, O'Dell JR, Stoner JA, Parrish LA, Arend WP, Norris JM, Holers VM (2004) Association of rheumatoid arthritis treatment response and disease duration with declines in serum levels of $\operatorname{IgM}$ rheumatoid factor and anti-cyclic citrullinated peptide antibody. Arthritis Rheum 50(12):3776-3782

14. Vis M, Bos WH, Wolbink G, Voskuyl AE, Twisk JW, Van de Stadt R, Hamann D et al (2008) IgM-rheumatoid factor, anticyclic citrullinated peptide, and anti-citrullinated human fibrinogen antibodies decrease during treatment with the tumor necrosis factor blocker infliximab in patients with rheumatoid arthritis. J Rheumatol 35(3):425-428

15. Yazdani-Biuki B, Stadlmaier E, Mulabecirovic A, Brezinschek R, Tilz G, Demel U, Mueller T et al (2005) Blockade of tumour necrosis factor alpha significantly alters the serum level of IgG- and IgA-rheumatoid factor in patients with rheumatoid arthritis. Ann Rheum Dis 64(8):1224-1226

16. De Rycke L, Verhelst X, Kruithof E, Van den Bosch F, Hoffman IE, Veys EM, De Keyser F (2005) Rheumatoid factor, but not anti-cyclic citrullinated peptide antibodies, is modulated by infliximab treatment in rheumatoid arthritis. Ann Rheum Dis 64(2):299-302

17. Plant M, Jones P, Saklatvala J, Ollier W, Dawes P (1998) Patterns of radiological progression in early rheumatoid arthritis: results of an 8 year prospective study. J Rheumatol 25(3):417-426

18. Aletaha D, Funovits J, Keystone EC, Smolen JS (2007) Disease activity early in the course of treatment predicts response to therapy after one year in rheumatoid arthritis patients. Arthritis Rheum 56(10):3226-3235

19. Familian A, Voskuyl AE, van Mierlo GJ, Heijst HA, Twisk JW, Dijkmans BA, Hack CE (2005) Infliximab treatment reduces complement activation in patients with rheumatoid arthritis. Ann Rheum Dis 64(7):1003-1008

20. Han C, Smolen JS, Kavanaugh A, van der Heijde D, Braun J, Westhovens R, Zhao N et al (2007) The impact of infliximab treatment on quality of life in patients with inflammatory rheumatic diseases. Arthritis Res Ther 9(5):R103

21. Caramaschi P, Biasi D, Tonolli E, Pieropan S, Martinelli N, Carletto A, Volpe A et al (2005) Antibodies against cyclic citrullinated peptides in patients affected by rheumatoid arthritis before and after infliximab treatment. Rheumatol Int 26(1):58-62

22. Atzeni F, Sarzi-Puttini P, Dell Acqua D, de Portu S, Cecchini G, Cruini C, Carrabba M et al (2006) Adalimumab clinical efficacy is associated with rheumatoid factor and anti-cyclic citrullinated 
peptide antibody titer reduction: a one-year prospective study. Arthritis Res Ther 8(1):R3

23. Braun-Moscovici Y, Markovits D, Zinder O, Schapira D, Rozin A, Ehrenburg M, Dain L et al (2006) Anti-cyclic citrullinated protein antibodies as a predictor of response to anti-tumor necrosis factoralpha therapy in patients with rheumatoid arthritis. J Rheumatol 33(3):497-500

24. Alessandri C, Bombardieri M, Papa N, Cinquini M, Magrini L, Tincani A, Valesini G (2004) Decrease of anti-cyclic citrullinated peptide antibodies and rheumatoid factor following anti-TNFalpha therapy (infliximab) in rheumatoid arthritis is associated with clinical improvement. Ann Rheum Dis 63(10):1218-1221

25. Bruns A, Nicaise-Roland P, Hayem G, Palazzo E, Dieudé P, Grootenboer-Mignot S, Chollet-Martin S et al (2009) Prospective cohort study of effects of infliximab on rheumatoid factor, anticyclic-citrullinated-peptide antibodies and antinuclear antibodies in patients with long-standing rheumatoid arthritis. Rev Rhum Engl Ed 76(5):410-416

26. Asaga H, Yamada M, Senshu T (1998) Selective deimination of vimentin in calcium ionophore-induced apoptosis of mouse peritoneal macrophages. Biochem Biophys Res Commun 243(3):641-646

27. Wang Y, Wysocka J, Sayegh J, Lee YH, Perlin JR, Leonelli L, Sonbuchner LS et al (2004) Human PAD4 regulates histone arginine methylation levels via demethylimination. Science 306(5694):279-283
28. Rönnelid J, Wick M, Lampa J, Lindblad S, Nordmark B, Klareskog L, van Vollenhoven R (2005) Longitudinal analysis of citrullinated protein/peptide antibodies (anti-CP) during 5 year follow up in early rheumatoid arthritis: anti-CP status predicts worse disease activity and greater radiological progression. Ann Rheum Dis 64(12): 1744-1749

29. van Gaalen FA, van Aken J, Huizinga TW, Schreuder GM, Breedveld FC, Zanelli E, van Venrooij WJ et al (2004) Association between HLA class II genes and autoantibodies to cyclic citrullinated peptides (CCPs) influences the severity of rheumatoid arthritis. Arthritis Rheum 50(7):2113-2121

30. Auger I, Sebbag M, Vincent C, Balandraud N, Guis S, Nogueira L, Svensson B et al (2005) Influence of HLA-DR genes on the production of rheumatoid arthritis-specific autoantibodies to citrullinated fibrinogen. Arthritis Rheum 52(11):3424-3432

31. Johansson M, Arlestig L, Hallmans G, Rantapaa-Dahlqvist S (2006) PTPN22 polymorphism and anti-cyclic citrullinated peptide antibodies in combination strongly predicts future onset of rheumatoid arthritis and has a specificity of $100 \%$ for the disease. Arthritis Res Ther 8(1):19-25

32. Potter C, Hyrich KL, Tracey A, Lunt M, Plant D, Symmons DP, Thomson W et al (2009) Association of rheumatoid factor and anti-cyclic citrullinated peptide positivity, but not carriage of shared epitope or PTPN22 susceptibility variants, with anti-tumor necrosis factor response in rheumatoid arthritis. Ann Rheum Dis 68:69-74 